\title{
Recurrence of gastric cancer in the transverse colon 10 years after gastrectomy
}

\author{
ORIGINAL ARTICLE Annals of Caner Research and Therapy
}

\author{
Tatsuo Makino · Yoshikazu Noguchi · Akira Tsuburaya · Kuniyasu Fukuzawa · \\ Katsutoshi Nomura - Takaki Yoshikawa - Toshio Imada · Tomishige Amano · Akihiko Matsumoto*
}

\begin{abstract}
A patient with gastric carcinoma which recurred as a solitary colonic metastasis 10 years after gastrectomy is reported. The patient was a 52-year-old man who had undergone total gastrectomy and pancreatico-splenectomy (Appleby's procedure) for Type 5 gastric carcinoma. Histologic examination showed poorly differentiated adenocarcinoma invading the gastric wall to reach the serosal surface (se) with limited lymph node metastases (to $\mathrm{n} 1$ nodes). He remained well until 10 years after surgery, when he developed epigastric pain and abdominal distention. Physical examination revealed a 10-cm-mass in the upper abdomen. Barium enema showed a circumferential stenosis at the midpoint of the transverse colon. Endoscopy showed that the colonic mucosa was edematous and featured an irregular cobblestone pattern, that was suggestive of submucosal infiltration.

Under the working diagnosis of recurrent gastric cancer, transverse colectomy was performed. Histologic examination revealed poorly differentiated adenocarcinoma that was very similar to the gastric carcinoma resected 10 years earlier. Although the tumor was transmural, it was more extensive at the serosal surface and the mucosa was intact. Judging from the mode of extension, this case was diagnosed as solitary recurrence of gastric carcinoma in the transverse colon from a microscopic tumor focus.
\end{abstract}

Ann Cancer Res Ther 2 (2) : 223 226, 1993 / Received 9 Dec 1993

Key worde : recurrent gastric cancer, Appleby operation, colon metastasis

It is not rare to encounter colonic involvement by gastric cancer associated with peritoneal dissemination or as a result of direct extension of the primary tumor. However, although the pattern of metastasis is diverse, localized metastasis of gastric cancer to the colon is very rare ${ }^{1)}$. We report a case of gastric cancer recurrence in the transverse colon at 10 years after extended radical surgery.

\section{Case report}

A 52-year-old man underwent total gastrectomy for gastric carcinoma in April 1976 (R2 node dissection and Roux-en-Y anastomosis) with Appleby's procedure ${ }^{2)}$, in which the body and tail of the pancreas, the spleen, and the common hepatic artery were resected en bloc together with the surrounding connective tissue. The tumor consisted of two ulcerative lesions on the lesser curvature in the middle part of stomach and was macroscopically classified as Type 5 carcinoma (Fig.1). Histologic examination revealed that it was a poorly differentiated adenocarcinoma which had reached the serosal surface (se, INF gamma). Lymph node metastases were confined to the $\mathrm{n} 1$ group; no. 1 group of the right cardiac nodes ( $2 / 7$ nodes ) and no. 3 group of the lesser curvature nodes (1/9 nodes) ${ }^{3)}$ (Fig.2). Blood vessels and

\footnotetext{
* First Department of Surgery, Yokohama City University School of Medicine
}

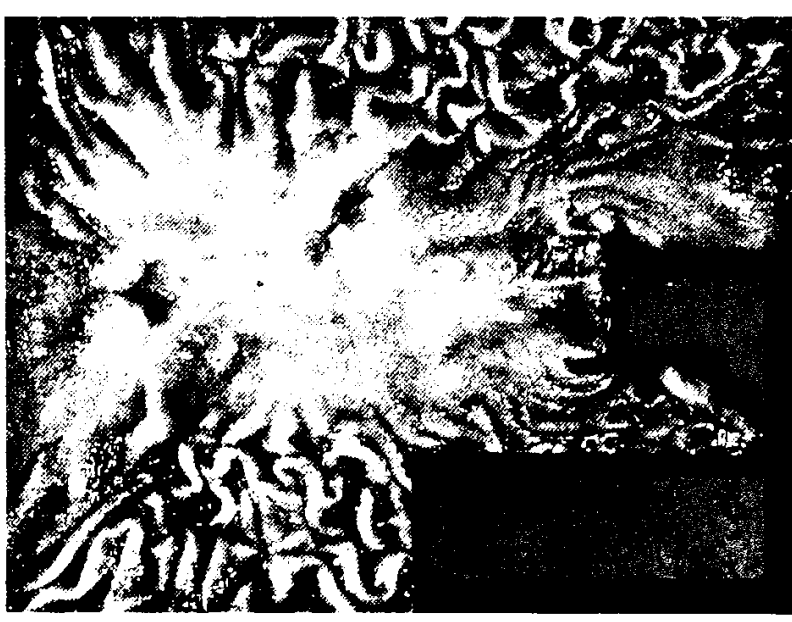

Fig.1 The resected stomach with two small ulcerative lesions on the lesser curvature of the mid-portion of the stomach

Macroscopically this was diagnosed as Type 5 carcinoma.

lymphatics were also invaded by the tumor ( 1 and ly2, respectively). The postoperative course was uneventful except for cholecystitis in 1976 and diabetes mellitus in 1979. Epigastric pain, abdominal distention and a change in bowel habits developed in June 1986. He was referred to our facility for further evaluation of a colonic stenosis that was found on a barium enema study ordered by the family doctor.

Physical examination on admission revealed a poorly nourished patient with a localized tender mass in the mid-abdomen. The mass was $10 \mathrm{~cm}$ in diameter and 


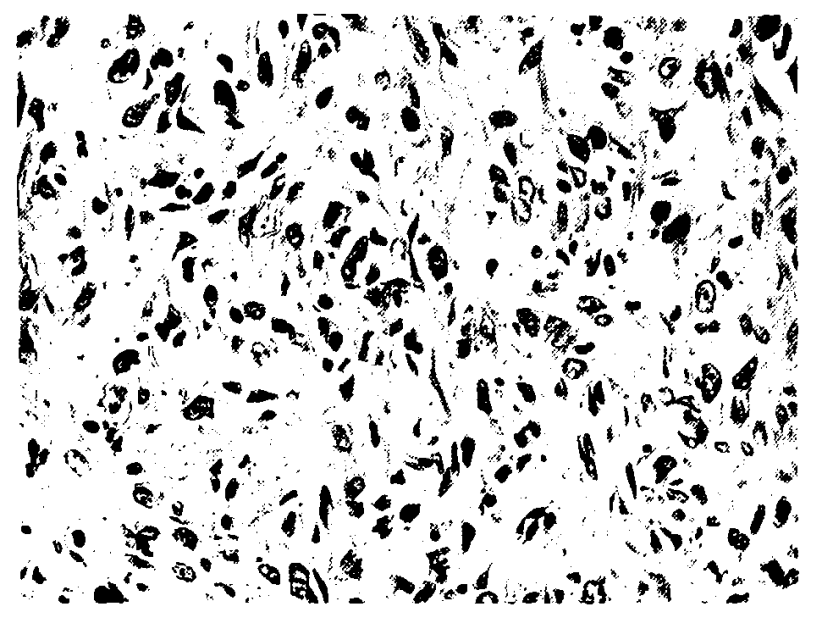

Fig.2 Histologic appearance of the resected gastric tumor Poorly differentiated adenocarcinoma is seen to be invading through the gastric wall (se). (HE stain, $\times 400$ )

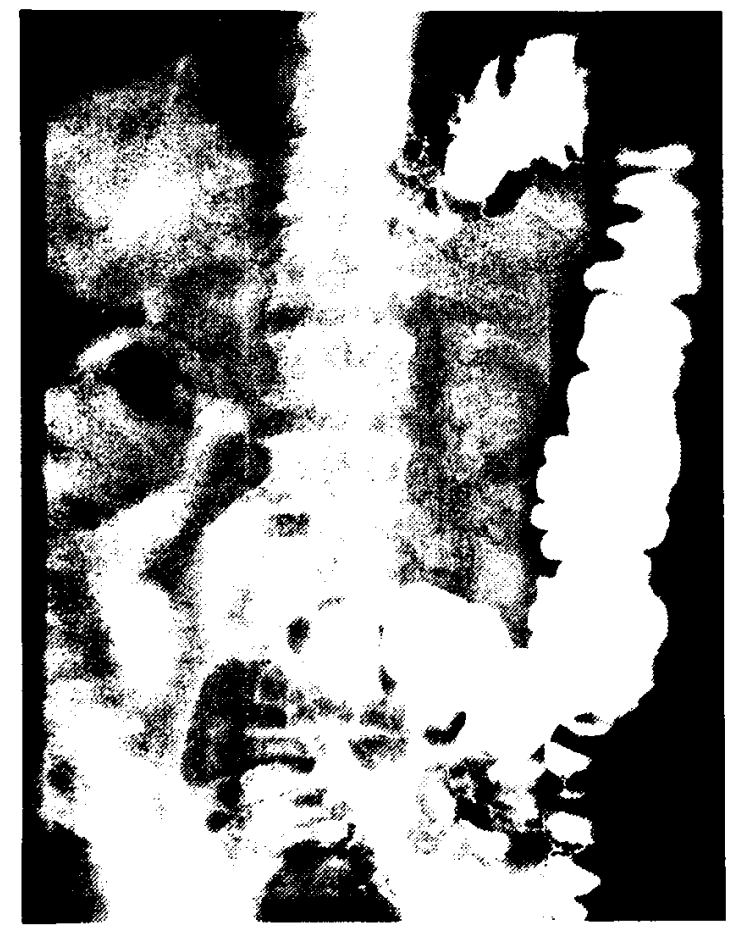

Fig.3 A barium enema reveals circumferential stenosis at the midpoint of the transverse colon

was only slightly mobile. Laboratory test results were unremarkable except for electrolyte abnormalities and hyperglycemia. A repeat barium enema showed complete obstruction at the midpoint of the transverse colon (Fig.3), and the mucosal surface distal to this site had a macronodular configuration. Colonoscopy showed that the mucosa at the stenosis was irregularly macronodular and edematous without any erosions or ulceration (Fig.4). Malignant cells were not detected by biopsy. Although a definite diagnosis was not made, exploratory laparotomy was performed to relieve the obstruction.

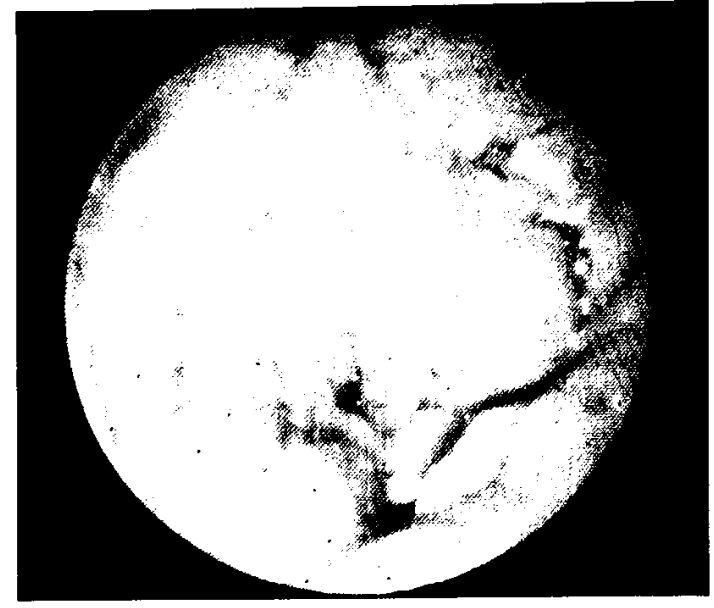

Fig.4 Endoscopy shows complete obstruction of the transverse colon and edematous mucosa, which features an irregular cobblestone pattern

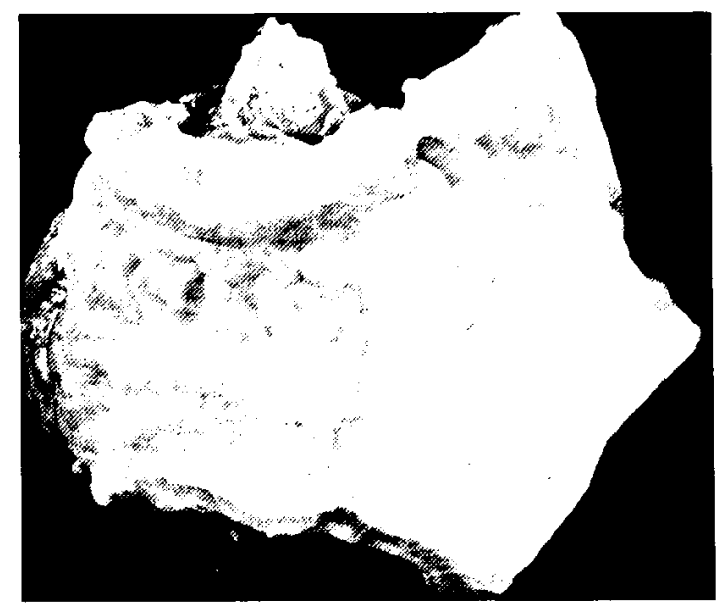

Fig.5 The resected specimen of the transverse colon, showing marked thickening of the bowel wall with intact mucosa

At operation, a $10-\mathrm{cm}$ mass was found at the midpoint of the transverse colon, with part of the small intestine adherent to it. This lesion was resected. The mucosal surface of the resected transverse colon was edematous, partly macronodular, and partly amorphous. The cut surface revealed marked thickening of the muscular and serosal layers (Fig.5). Histologic examination showed poorly differentiated cancer cells invading the subserosa and extending to the submucosa with the mucosal layer being intact. These findings were suggestive of invasion from outside the colon (Fig.6). Cancer cells were detected in the oral margin of the surgical specimen (ow (t)), but the anal margin was free of tumor (aw $(-))$. On the basis of the pattern of invasion and the strong histologic similarity of the tumors, this lesion was diagnosed as a metastasis from the gastric carcinoma resected 10 years previously. The patient died of the disease at 16 months after the second operation. 


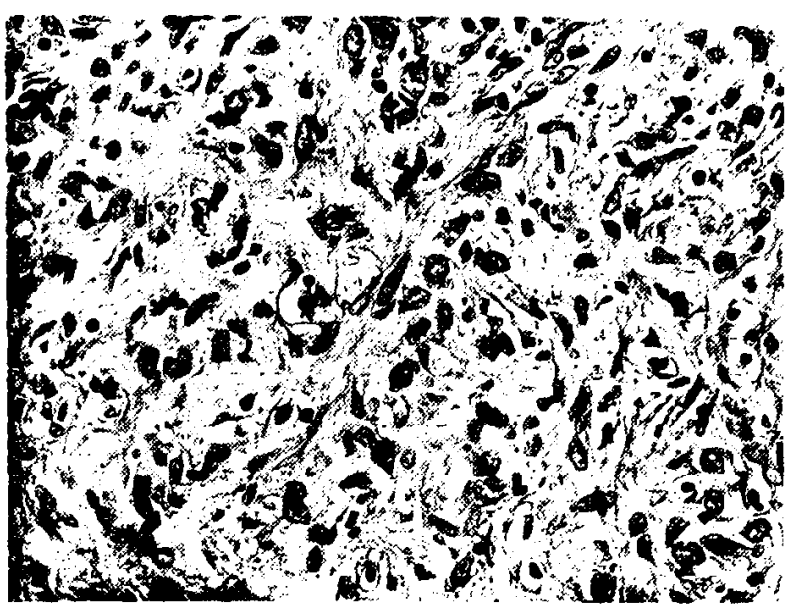

Fig.6 Histologic appearance of the resected colon Irregularly shaped tumor cells were scattered without forming glands, infiltrating the serosal region more markedly than the mucosa, which remained intact.

The tumor cells were very similar to the gastric cancer resected 10 years earlier (Fig.2). (HE stain, $\times 400$ )

\section{Discussion}

Approximately $80 \%$ of recurrent gastric carcinomas occur within 5 years after surgery ${ }^{4}$. In our previous study, most recurrences after curative surgery occurred within 3 years $(86.5 \%)$, and those that recurred after 5 years were either Stage I $(75 \%)$ or Stage II $(25 \%)$, with $60 \%$ of late recurrences being local ${ }^{5}$.

Although solitary metastasis of gastric carcinoma to the colon is relatively rare, it is noteworthy that $40 \%$ of such cases present between 5 and 10 years after surgery. Only two cases, including ours, have presented more that 10 years after the initial surgery ${ }^{6)}$. The primary tumors were macroscopically Borrmann Type 3 cancer located in the mid-portion of the gastric body, and histologic examination revealed poorly differentiated adenocarcinoma that reached the serosal surface (se) with limited lymph node metastasis to an $\mathrm{nl}$ group ${ }^{1,7}$. The transverse colon was the most frequently involved site (in five out of six cases, including ours), probably due to the presence of the greater omentum and the proximity of the colon to the stomach.

Imada has demonstrated that microscopic foci of peritoneal dissemination on the greater and lesser omentum are not rare and that disseminated metastasis can also arise from metastatic lymph nodes, if the capsule is ruptured by tumor invasion ${ }^{\mathrm{s}}$. As our patient was in stage III due to the $\mathbf{2} 2$ factor $^{3)}$ at the time of initial surgery, it is likely that the metastasis arose from a small disseminated focus, although the possibility of hematogenous or lymphatic metastasis cannot be excluded. Our previous work on the lymphatic drainage of the stomach using activated charcoal has revealed that deposits in the greater omentum which are morphologically similar to peritoneal dissemination can arise from lymphatic spread.

The serosal invasion and limited lymph node metastasis without vascular or lymphatic involvement at the primary tumor site as well as the extensive infiltration of cancer cells in the subserosa of the secondary lesion, suggest that this lesion arose from a few cancer cells disseminated locally to the colonic wall ${ }^{7,9}$. In order to detect such small foci on the omentum, methylene blue staining of the resected specimen may be useful ${ }^{10)}$, but the clinical significance of such findings in predicting late metastases remains to be elucidated. These lesions have to be distinguished from linitis plastica colon carcinoma ${ }^{11}$, which often resembles a metastatic lesion. Although linitis plastica of the colon more frequently involves the rectum and sigmoid colon, this cannot be a definite criterion for making a differential diagnosis. In contrasts the mode of intramural extension of the lesion may provide a key to the diagnosis.

Although it is not common to find a resectable recurrence after radical gastrectomy, long-term followup is necessary to detect recurrences originating from localized microscopic dissemination, which can present even 10 years after the initial surgery.

\section{References}

1) Niimi K, Matsuki $K$, Tomoda $K$ : Two cases of solitary metastasis to the large intestine from gastric carcinoma. Jpn J Cancer Clin 30 : 1720-1725, 1984.

2) Appleby LH: The celiac axis in the expansion of the operation for gastric cancer. Cancer 6 : 704-727. 1963.

3) Japanese Research Society for Gastric Cancer : The general rules for the gastric cancer study in surgery and pathology. Jpn J Surg, 11 : 127-139, 1981.

4) Kano T, Kumashiro R, Masuda H, Okumura T, Inokuchi $K$ : Recurrent gastric carcinoma-analysis of 100 in-patients - Jpn $\mathrm{J}$ Surg, 13 : 106-111, 1983.

5) Noguchi $Y$, Imada $T$, Makino $T$, Suzuki $H$, Abe $M$, Tamura $S$, Yamamoto Y, Amano T, Matsumoto A. : Clinical course of gastric carcinoma recurrence after surgery. J Jpn Soc Clin Surg, 49 : 584 $589,1988$.

6) Fuku H, Sato T, Nishiba R, Higashiyama H, Takarada $Y$, Aoki D, Yabana T, Akiyama T : A case of secondary Linitis Plastical of the colon developing 14 years after gastrectomy for advanced carcinoma. Jpn J Cancer Clin, 32 : 2009-2014, 1986.

7) Furuta $Y$, Shimazu $H$, Suguhara $K$, Sawada $T$, Muto $T$, Tomiyama $J$, Morioka $Y$ : Diffusely infiltrating type of carcinoma of the colon secondary to metastasis or recurrence of the gastric cancer. Geka (Surgery), $44: 587-592,1982$, (in Japanese).

8) Imada $T$ : Mechanism by which peritoneal disseminated metastasis develops in gastric cancer. J Jpn Surg Soc, 87 : 593-603, 1986.

9) Ishida N, Yoshimine S, Yoshimura A, Kita T, Hidaka N : An operative case of metastatic carcinoma of the small intestine presenting as small bowel obstruction 3 years and 5 months after curative resection for gastric carcinoma. J Jpn Soc Clin Surg, 47 : 1609-1613, 1986, (in Japanese). 
10) Noguchi $Y$, Imada $T$, Matsumoto. A, Coit DG, Brennan MF : Radical surgery for gastric cancer. A review of the Japanese experience. Cancer, $64: 2053-2062,1989$.
11) Andersen JA, Hansen BF : Linitis plantica of the colon and rectum report of two cases - . Dis Colon Rectum, $15:$ 217-221, 1972. 
PAM療法が13.8\%，MVP療法が19.0\%であった．肺癌の 大部分をしめる腺癌と扁平上皮癌についてプロトコール 別に有効率をみると，腺癌に対してPV療法は $14.8 \%$, MVP療法は17.6\%であり，扁平上皮癌に対してPV療法は 23.8\%，MVP療法は42.1\%であり，特に扁平上皮癌に対 するMVP療法の有用性が示唆された. retorospectiveに臨 床効果との相関性が評価可能な26症例のうち観察期間の 短い症例を除く24例の臨床相関性は true positiveが4例, true negativeが15例, false negativeが5例であった。 以上 より鶏卵法の肺癌に対する臨床での併用化学療法の予測 率は79.2\%であった。

[考 察] 肺癌は比較的早期加遠隔転移を生じゃ すいという䁍器特異性があり，予後の改善には術後の全 身化学療法の併用が不可欠である。したがって, 肺癌の 個々の症例に対して有効な術後の多剂併用化学療法が選 択できる抗癌剤感受性試験法が開発されれば，肺癌の治 療成績の向上に大きく貢献できると考えられる．本研究 は，臨床に即した多剤併用化学療法を評価できる感受性 試験法としてin vivo雞卵法の基䃈的な検討を行い, 臨床 効果との相関性を検討した。鵎卵法を用いた感受性試験 法は，短期間に効果判定が可能であり，試験成功率も高 く，肺癌に対する多剂併用療法が的確に評価可能である.

さらに，臨床効果の予測率が高く，再現性も良いこと から，有用な抗癌剤感受性試験であると考えられた。

\section{Recurrence of gastric cancer in the transverse colon 10 years after gastrectomy p 223 226}

\section{Tatsuo Makino et al.}

胃癌の直接浸閏または腹膜播種による横行結腸再発は けっしてまれではなが, 横行結腸への孤立性再発は非 常にまれである，今回筆者らは，胃癌根治術後10年目に 横行結腸に孤立性の再発をきたした1例を経験したので 報告する。

症例は52歳の男性で，1976年に胃癌に対してAppleby 手術を施行した，肉眼的にはM領域症小弯を中心とした 潰瘍性病変であり，組織学的には低分化腺癌でse, n1で あった．術後経過は非常に順調であったが，1986年満腹 感を主訴に近医を受診し，注腸検查にて横行結腸の狭窄 を指摘され当科を受診した，大腸内視鏡検査では，狭窄 部位粘膜は浮腫を伴った不規則な多数の結節を呈してい たが，濽場性病変は認められなかった。また，生検では 覀性組織は得られなかった。確定診断つかないも狭窄部 位切除の目的で手術を施行した。開腹所見では，横行結 腸の中央部に約 $10 \mathrm{~cm}$ の腫㾞を認め，横行結腸切除術を 施行した。標本の粘膜面は浮腫状を呈しており，一部に 結節を形成していた，組織学的には獎膜下を中心に低分 化腺癌を認め，癌細胞は粘膜下にまで達していたが粘膜 面は正常であり，結腸外から浸閏してきたものと考えら れた。 また，癌組織所見が前回の胃癌組織と非常に類似 しており，以上より胃癌術後10年目に横行結腸再発をき たした症例と診断した。

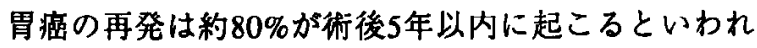

ており，筆者らの施設でも，86.5\%が治瘾切除後3年以 内に起こっている。

胃癌の大腸への孤立性転移という形での再発例はまれ であり，筆者らの症例を含めて検討してみると，約 $40 \%$ のものは5年以上経過してから再発しており注目すべき 点である。また，肉眼型はBorrmann3型で，胃体中部に 存在するものが多く，進達度はすべてss $\gamma$ あるいはse ps (十)の症例である.この症例はse，n1であり，大腸へ の転移経路としては腹膜播種がもっとも考えられるが, 血行性, リンパ行性に起こった可能性も否定しきれない. また, linitis plastica型の大腸癌との鑑別も必要である. たたこの型のものは圧倒的に直腸，S状結腸に発生する ものが多く，横行結腸という部位，腸管壁内の癌の進展 形式などより，筆者らの症例は胃癌の孤立性転移と考え られた。

胃癌術後再発例において，切除できる症例は多くはな いが，10年経過してから再発を確認し切除できる症例も あり，手術後長期にわたる経過観察は非常に重要である と思われた。 